\title{
Nutritional reserves of Vochysiaceae seeds: chemical diversity and potential economic uses
}

\author{
MARCO A.S. MAYWORM ${ }^{1}$, MARCOS S. BUCKERIDGE ${ }^{2}$, \\ URSULA M.L. MARQUEZ ${ }^{3}$ and ANTONIO SALATINO ${ }^{2}$ \\ ${ }^{1}$ Faculdade de Biologia, Universidade de Santo Amaro/UNISA \\ Rua Prof. Eneas de Siqueira Neto, 340, 04829-300 São Paulo, SP, Brasil \\ ${ }^{2}$ Departamento de Botânica, Instituto de Biociências, Universidade de São Paulo \\ Rua do Matão, 277, 05508-910 São Paulo, SP, Brasil \\ ${ }^{3}$ Departamento de Alimentos, Faculdade de Ciências Farmacêuticas, Universidade de São Paulo \\ Av. Lineu Prestes, 580, Bl. 13A, 05508-900 São Paulo, SP, Brasil \\ Manuscript received on November 23, 2009; accepted for publication on August 9, 2010
}

\begin{abstract}
Contents of proteins, carbohydrates and oil of seeds of 57 individuals of Vochysiaceae, involving one species of Callisthene, six of Qualea, one of Salvertia and eight of Vochysia were determined. The main nutritional reserves of Vochysiaceae seeds are proteins (20\% in average) and oils (21.6\%). Mean of carbohydrate contents was 5.8\%. Callisthene showed the lowest protein content (16.9\%), while Q. cordata was the species with the highest content (30\% in average). The contents of ethanol soluble carbohydrates were much higher than those of water soluble carbohydrates. Oil contents lay above $20 \%$ for most species (30.4\% in V. pygmaea and $V$. pyramidalis seeds). The predominant fatty acids are lauric (Q. grandiflora), oleic (Qualea and Salvertia) or acids with longer carbon chains (Salvertia and a group of Vochysia species). The distribution of Vochysiaceae fatty acids suggests for seeds of some species an exploitation as food sources (predominance of oleic acid), for other species an alternative to cocoa butter (high contents or predominance of stearic acid) or the production of lubricants, surfactants, detergents, cosmetics and plastic (predominance of acids with $\mathrm{C}_{20}$ or $\mathrm{C}_{22}$ chains) or biodiesel (predominance of monounsaturated acids). The possibility of exploitation of Vochysiaceae products in a cultivation regimen and in extractive reserves is discussed.
\end{abstract}

Key words: biodiesel, carbohydrates, fatty acids, proteins, seed oils, Vochysiaceae.

\section{INTRODUCTION}

The family Vochysiaceae comprises approximately 200 predominantly shrubby and tree species, distributed into eight Neotropical genera, except Erismadelphus, a genus native in Western Africa. In Brazil, there are nearly 150 species, included in the genera Callisthene, Erisma, Euphronia, Qualea, Ruizterania, Salvertia (monotypic) and Vochysia (Souza and Lorenzi 2005).

The beauty of Vochysiaceae flowers, sometimes gathered in compact inflorescences, such as in most Vochysia species, implying a potential as ornamentals

Correspondence to: Antonio Salatino

E-mail: asalatin@ib.usp.br so far unexploited, has been stressed (Ducke and Black 1953, de Paula 1967). The wood of V. tetraphylla (Mey.) DC. is used for furniture manufacture and that of $V$. hondurensis Sprague for the construction of boats and fence pillars. The seeds of E. calcaratum (Link) Warm. are sources of the so called jaboti butter, which is used for soap and candle production (Heywood 1993). The japurá (E. japura Spruce ex Warm.) has oleaginous seeds, which are eaten raw, toasted, boiled or as butter of japurá by the native Indians in Northern Brazil (Cavalcante 1991, Dubois 1996). Q. grandiflora has seeds with high content of oil, whose predominant fatty acid is oleic (Mayworm and Salatino 1996). 
A dye is obtained from the bark of some Qualea species. From the fermented sap of some Vochysia species a drink similar to wine is obtained (Barroso 1984). Plants of $V$. bifalcata Warm. release a material similar to Arabic gum. This material may be used as an adhesive to agglutinate pharmaceutical tablets and possesses similar degrees of friability and hardness, although gum Arabic has a faster disaggregating time (Zamur et al. 1981). The bark of $V$. divergens, a species frequently found in the pantanal of Mato Grosso, has been used in popular medicine for the treatment of wounds and asthma and contains high amounts of sericic acid, a compound with anti-inflammatory and wound-healing activities (Hess et al. 1995). Such finding is in accordance with properties assigned to the plant in popular medicine. Extracts from Q. multiflora and $S$. convallariodora have been reported to have moluscicidal activity (Souza et al. 1984).

Species of Vochysiaceae have oily seeds. E. calcaratum has seeds with oil contents up to $53 \%$, with predominance of myristic, lauric and palmitic acids (Banerji et al. 1984). Seeds of $V$. hondurensis have 28\% of oil, in which oleic, arachidic and eicosanoic acids predominate, in addition to $34 \%$ protein and $2.2 \%$ carbohydrates (Blanche et al. 1991). The distribution of Vochysiaceae seed fatty acids has been studied with taxonomic aims and has been shown to be highly diverse and taxonomically meaningful (Mayworm and Salatino 2002).

Seed carbohydrates have also been investigated in Vochysiaceae. The distinction among genera is possible on the basis of monosaccharide composition (Mayworm et al. 2000). Polysaccharide composition of seed Vochysiaceae is compatible with the presence of a mixture of arabinogalactan and mannan. Such mixture has a striking resemblance to soluble coffee carbohydrate composition (Mayworm et al. 2000).

Vochysiaceae seeds are in general winged and wind dispersed, with the endosperm area bilaterally compressed and located at the base of the seed.

Several reasons point out to the urgent need of efforts aiming at the composition of seeds from plants native to Brazil: 1) the high relevance of seeds in human and animal diets and as sources of products for industrial uses; 2) the megadiversity of the Brazilian flora; 3) the limited knowledge of seed composition. The present work reports the carbohydrate, protein and oil contents of seeds of Brazilian Vochysiaceae and raises comments about possible economic exploitation.

\section{MATERIALS AND METHODS}

Fruits of 57 specimens were collected in the states of São Paulo, Minas Gerais, Bahia, Goiás and Tocantins. Voucher specimens are deposited at the herbaria of the Institute of Biosciences of the University of São Paulo (SPF) and of the State University of Feira de Santana, Bahia (HUEFS). Table I lists the samples analyzed, corresponding voucher numbers and localities of collection. The fruits were kept in the shade at room temperature until dehiscence and release of the seeds, which were stored at $-18^{\circ} \mathrm{C}$. The sizes of the seeds analyzed varied depending on the species. $V$. pyramidalis has the smallest, which are $1.5 \mathrm{~cm}$ long and $0.5 \mathrm{~cm}$ wide and, including the wing; the endosperm region is $0.5 \mathrm{~cm}$ long. Plants of $S$. convallariodora have the largest seeds: $5.0 \mathrm{~cm}$ long and $1.5 \mathrm{~cm}$ wide, the endosperm region $2.0 \mathrm{~cm}$ long. $V$. rufa has seeds with the higher proportion of endosperm volume and mass.

All analyses described below were performed in triplicates.

\section{LIPID EXTRACTION AND ANALYSIS}

Duplicate samples containing 2-5 g of seeds previously dried in ventilated oven at $60^{\circ} \mathrm{C}$ were ground and homogenized. The samples were extracted with $n$-hexane in Soxhlet for $10 \mathrm{~h}$. The solvent was eliminated in rotatory evaporator under reduced pressure and the extracted oil was maintained in desiccator until constant weight (Ahmad et al. 1981). The distribution of the predominant fatty acids in the compositions of seed oils in Table I is based on data published previously (Mayworm and Salatino 2002).

\section{Protein Contents - Total Nitrogen AnALysis}

The determination of total nitrogen contents was carried out using micro-Kjeldhal method. After the lipid extraction, $50 \mathrm{mg}$ of each sample was placed in a test tube to which $2 \mathrm{~g}$ of $\mathrm{K}_{2} \mathrm{SO}_{4}, 0.1 \mathrm{~g}$ of $\mathrm{CuSO}_{4}$ and $3 \mathrm{~mL}$ of $\mathrm{H}_{2} \mathrm{SO}_{4}$ were added. The digestion of the samples 
took place at $350^{\circ} \mathrm{C}$ until the material became greenish colored. Heating was maintained for an additional period of 4 h. $3 \mathrm{~mL}$ of water and $15 \mathrm{~mL}$ of $40 \% \mathrm{NaOH}$ were added and a distillation was carried out. $5 \mathrm{~mL}$ of 55.5 g. $\mathrm{L}^{-1}$ boric acid was added to the collected distilled liquid, after which the solution was titrated with $0,02 \mathrm{~N} \mathrm{HCl}$. Factor 6.25 was used to convert nitrogen to protein content, since de Codex Committee on Nutrition and Foods for Special Dietary Uses estates that such factor "should be used, unless a scientific justification is provided for the use of a different conversion factor for a particular nitrogen source" (Bulletin of the International Dairy Federation 2006).

\section{EXTRACTION OF MONO AND OLIGOSACCHARIDES}

Mono and oligosaccharides were extracted from $100 \mathrm{mg}$ of the powdered samples with $1.0 \mathrm{~mL}$ of $80 \%$ ethanol in Eppendorf tubes in $80^{\circ} \mathrm{C}$ bath for $1 \mathrm{~h}$. The tubes were centrifuged at $13,000 \mathrm{~g}$ at $5^{\circ} \mathrm{C}$ for $7 \mathrm{~min}$. Four extractions were carried out for each sample and the supernatants were pooled, corresponding to the ethanol fraction of the sample.

\section{Soluble Polysaccharides EXtraction}

Water soluble polysaccharides were extracted in Eppendorf tubes with distilled water in $80^{\circ} \mathrm{C}$ bath for $3 \mathrm{~h}$. The tubes were centrifuged at $13,000 \mathrm{~g}$ at $5^{\circ} \mathrm{C}$ for $7 \mathrm{~min}$. Four extractions were carried out and the supernatants pooled. Four volumes of ethanol were added and the solutions kept in freezer for $15 \mathrm{~h}$. The samples were centrifuged at $13,000 \mathrm{~g}$ at $5^{\circ} \mathrm{C}$ for $5 \mathrm{~min}$ and the supernatant discarded. The residue was re-suspended in distilled water. The suspension obtained corresponds to the aqueous fraction of the sample.

\section{Total Carbohydrate Contents}

Contents of total sugars from both ethanol and aqueous fractions were determined by the phenol-sulfuric method (Dubois et al. 1956). Volumes used for each fraction were $30-50 \mu \mathrm{L}$; the final volume was made up to $1.0 \mathrm{~mL}$ with water. $0.5 \mathrm{~mL}$ of $5 \%$ phenol and $2.5 \mathrm{~mL}$ of concentrated $\mathrm{H}_{2} \mathrm{SO}_{4}$ were added. After $30 \mathrm{~min}$, absorbance was measured at $490 \mathrm{~nm}$ (Beckman U70). A calibration curve was constructed using glucose as standard.

\section{RESULTS AND DISCUSSION}

\section{Nutritional Reserve Profiles}

Table I shows the contents of carbohydrates, proteins, oils and respective predominant fatty acids of the Vochysiaceae seeds analyzed. Previously published data regarding fatty acid composition of lipid fraction of these seeds appear also in Table I for a discussion of their possible economic use. In general, standard deviation values amounted to less than $1 \%$. On dry weight basis, protein contents ranged from 14 to $33 \%$, carbohydrates from 3 to $9 \%$ (combining results from both ethanol and aqueous extracts) and oils from 5 to $32 \%$. Taking into account results of all samples, the means regarding proteins carbohydrates and to oils are, respectively, 20\%, 5.4\% and $21.6 \%$. Thus, predominant energetic reserves in Vochysiaceae are proteins and oils. Such values agree with data of several seeds used in human nutrition, with a negative correlation between contents of protein and carbohydrates and between lipids and carbohydrates (Simpson and Ogorzaly 1995). Seeds of Vochysia hondurensis contain 28.6\%, 34\% and 4.2\% of oil, protein and carbohydrates, respectively (Blanche et al. 1991), in agreement with several data of Table I.

Protein contents of Vochysiaceae (Table I) are similar to those of Amaranthaceae (Rajyalakshmi and Geervani 1994, Zheleznov et al. 1997), Malvaceae (Earle et al. 1960, Kittur et al. 1982, Rao 1996), Meliaceae (Kleiman and Payne-Wahl 1984, Sundar Rao and Lakshminarayana 1987, Sotelo et al. 1990), Rubiaceae (Earle et al. 1960) and Sterculiaceae (Earle et al. 1960, Mustafa et al. 1986, Sotelo et al. 1990). Callisthene seeds showed $17 \%$ of proteins, the lowest value so far reported for Vochysiaceae. Qualea seeds presented the lowest (14\% in average, Q. grandiflora) and the highest (30\% in average, Q. cordata) contents of proteins in the family (Table I). Similar contents (19-22\%) characterize seeds of $Q$. dichotoma and $Q$. cryptantha, and higher values (20-30\%) were obtained with seeds of $Q$. parviflora and $Q$. cordata (Table I). A wide variation of protein contents was noted among samples of Salvertia convallariodora, in the range 14-24\% (Table I). In spite of overlapping contents of protein among species of Vochysia, due to intraspecific variation, in general contents are lower (17-18\%) in $V$. rufa, $V$. lucida, 
TABLE I

Yield (percentage of seed dry weight) of protein, sugars and lipids of seeds from Vochysiaceae. The last column shows main compounds of the distribution of seed oils, based on previously published data (Mayworm and Salatino 2002).

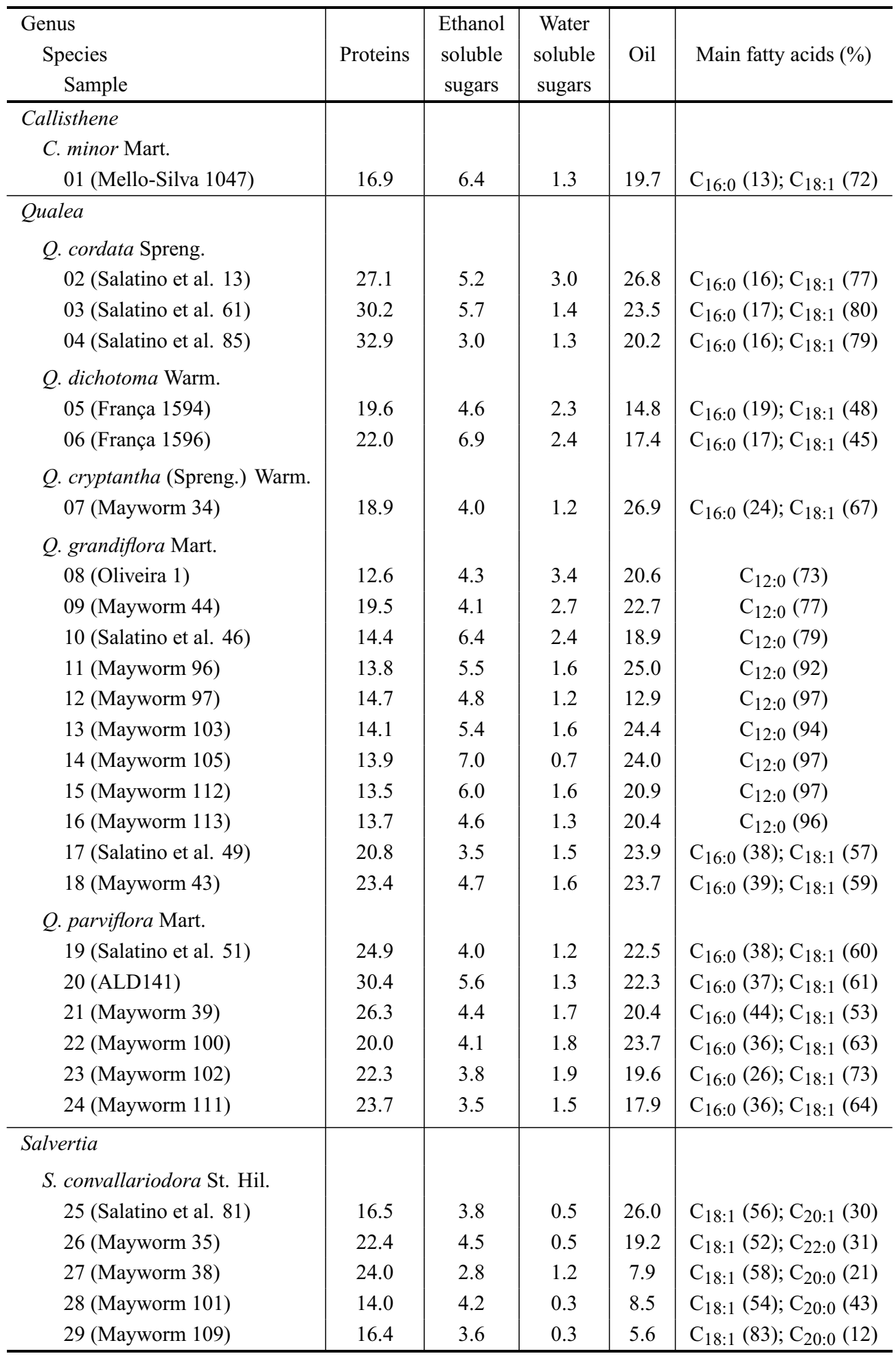


TABLE I (continuation)

\begin{tabular}{|c|c|c|c|c|c|}
\hline $\begin{array}{l}\text { Genus } \\
\text { Species } \\
\text { Sample }\end{array}$ & Proteins & $\begin{array}{l}\text { Ethanol } \\
\text { soluble } \\
\text { sugars }\end{array}$ & $\begin{array}{c}\text { Water } \\
\text { soluble } \\
\text { sugars }\end{array}$ & Oil & Main fatty acids (\%) \\
\hline \multicolumn{6}{|l|}{ Vochysia } \\
\hline \multicolumn{6}{|l|}{ V. elliptica Mart. } \\
\hline 30 (Salatino et al. 48) & 24.2 & 4.0 & 0.4 & 25.4 & $\mathrm{C}_{18: 0}(29) ; \mathrm{C}_{18: 1}$ \\
\hline 31 (Salatino et al. 65) & 25.2 & 3.6 & 0.4 & 26.0 & $\mathrm{C}_{18: 0}(14) ; \mathrm{C}_{18: 1}(80)$ \\
\hline 32 (Mayworm 27) & 20.1 & 4.4 & 0.6 & 27.8 & $\mathrm{C}_{18: 0}(27) ; \mathrm{C}_{18: 1}(55)$ \\
\hline 33 (Mayworm 30) & 18.1 & 4.8 & 1.1 & 24.2 & $\mathrm{C}_{18: 0}(30) ; \mathrm{C}_{18: 1}$ (49) \\
\hline 34 (Mayworm 31) & 23.6 & 4.8 & 0.9 & 27.0 & $\mathrm{C}_{18: 0}(23) ; \mathrm{C}_{18: 1}(57)$ \\
\hline \multicolumn{6}{|l|}{ V. gardneri Warm. } \\
\hline 35 (Mayworm 41) & 22.4 & 5.3 & 0.7 & 27.1 & $\mathrm{C}_{18: 0}(26) ; \mathrm{C}_{18: 1}$ \\
\hline 36 (Mayworm 42) & 22.0 & 3.9 & 0.6 & 22.9 & $\mathrm{C}_{18: 0}(19) ; \mathrm{C}_{18: 1}$ \\
\hline 37 (Mayworm 99) & 15.3 & 3.6 & 0.3 & 8.8 & $\mathrm{C}_{18: 0}(6) ; \mathrm{C}_{18: 1}(70)$ \\
\hline \multicolumn{6}{|l|}{ V. rufa Mart. } \\
\hline 38 (Mayworm 107) & 17.2 & 3.5 & 0.3 & 10.4 & $\mathrm{C}_{18: 0}(12) ; \mathrm{C}_{18: 1}(83)$ \\
\hline 39 (Mayworm 108) & 17.6 & 3.5 & 0.1 & 7.7 & $\mathrm{C}_{18: 0}(36) ; \mathrm{C}_{18: 1}(58)$ \\
\hline 40 (Mayworm 110) & 18.4 & 3.6 & 0.4 & 12.1 & $\mathrm{C}_{18: 0}(9) ; \mathrm{C}_{18: 1}(88)$ \\
\hline 41 (Mayworm 114) & 17.8 & 3.1 & 0.2 & 10.6 & $\mathrm{C}_{18: 0}(11) ; \mathrm{C}_{18: 1}(82)$ \\
\hline \multicolumn{6}{|l|}{ V. lucida Presl. } \\
\hline 42 (Mayworm 63) & 17.8 & 2.9 & 0.4 & 19.8 & $\mathrm{C}_{18: 1}(28) ; \mathrm{C}_{20: 0}(19) ; \mathrm{C}_{20: 1}(49)$ \\
\hline 43 (Mayworm 64) & 21.1 & 3.0 & 0.8 & 27.9 & $\mathrm{C}_{18: 1}(32) ; \mathrm{C}_{20: 0}(11) ; \mathrm{C}_{20: 1}(40)$ \\
\hline 44 (Mayworm 65) & 20.2 & 2.4 & 0.6 & 28.4 & $\mathrm{C}_{18: 1}(28) ; \mathrm{C}_{20: 0}(13) ; \mathrm{C}_{20: 1}(52)$ \\
\hline \multicolumn{6}{|l|}{ V. pygmaea Bongard } \\
\hline 45 (Salatino et al. 74) & 17.9 & 3.9 & 0.7 & 30.4 & $\mathrm{C}_{18: 1}(28) ; \mathrm{C}_{20: 1}(29) ; \mathrm{C}_{22: 1}(17)$ \\
\hline \multicolumn{6}{|l|}{ V. thyrsoidea Pohl. } \\
\hline 46 (Salatino et al. 57) & 19.9 & 3.2 & 0.5 & 25.6 & $\mathrm{C}_{18: 1}(16) ; \mathrm{C}_{20: 1}(29) ; \mathrm{C}_{22: 0}(13) ; \mathrm{C}_{22: 1}(25)$ \\
\hline 47 (Salatino et al. 86) & 19.6 & 2.8 & 0.4 & 23.1 & $\mathrm{C}_{18: 1}(12) ; \mathrm{C}_{20: 1}(27) ; \mathrm{C}_{22: 0}(12) ; \mathrm{C}_{22: 1}(26)$ \\
\hline 48 (Mayworm 95) & 23.1 & 3.9 & 0.3 & 12.7 & $\mathrm{C}_{18: 1}(11) ; \mathrm{C}_{20: 1}(25) ; \mathrm{C}_{22: 0}(14) ; \mathrm{C}_{22: 1}(46)$ \\
\hline \multicolumn{6}{|l|}{ V. tucanorum Mart. } \\
\hline 49 (Godoy 516) & 17.2 & 4.5 & 0.5 & 25.8 & $\mathrm{C}_{18: 1}(15) ; \mathrm{C}_{20: 1}(28) ; \mathrm{C}_{22: 1}(21)$ \\
\hline $50($ ALD 142) & 17.4 & 4.5 & 0.6 & 27.6 & $\mathrm{C}_{18: 1}(14) ; \mathrm{C}_{20: 1}(25) ; \mathrm{C}_{22: 1}(20)$ \\
\hline 51 (Mayworm 45) & 17.2 & 5.3 & 0.2 & 28.4 & $\mathrm{C}_{18: 1}(14) ; \mathrm{C}_{20: 1}(28) ; \mathrm{C}_{22: 1}$ \\
\hline \multicolumn{6}{|l|}{ V. pyramidalis Mart. } \\
\hline 52 (França 1575) & 19.8 & 4.0 & 0.5 & 31.6 & $\mathrm{C}_{18: 0}(43) ; \mathrm{C}_{18: 1}(37)$ \\
\hline 53 (Mayworm 68) & 21.8 & 3.9 & 0.7 & 23.2 & $\mathrm{C}_{18: 0}(28) ; \mathrm{C}_{18: 1}(55)$ \\
\hline 54 (Mayworm 69) & 20.0 & 3.9 & 0.5 & 25.2 & $\mathrm{C}_{18: 0}(27) ; \mathrm{C}_{18: 1}(54)$ \\
\hline 55 (Mayworm 70) & 20.6 & 5.0 & 0.6 & 30.2 & $\mathrm{C}_{18: 0}(27) ; \mathrm{C}_{18: 1}(57)$ \\
\hline 56 (Mayworm 72) & 19.2 & 3.8 & 0.6 & 30.7 & $\mathrm{C}_{18: 0}(34) ; \mathrm{C}_{18: 1}(44)$ \\
\hline 57 (Mayworm 73) & 22.4 & 3.8 & 1.0 & 30.4 & $\mathrm{C}_{18: 0}(35) ; \mathrm{C}_{18: 1}(48)$ \\
\hline
\end{tabular}


$V$. pygmaea and $V$. tucanorum, and higher (20-22\%) in $V$. elliptica, $V$. gardneri, $V$. thyrsoidea and $V$. pyramidalis (Table I).

In several plant families, part of total seed nitrogen corresponds to substances other than proteins, such as non-protein aminoacids, alkaloids and cyanogenic glycosides. Regarding Vochysiaceae seeds, no mention of such substances has been reported so far.

In general, mean contents of mono and oligosaccharides from ethanol extracts of Callisthene and Qualea seem to be higher than those observed in Salvertia and Vochysia (Table I). The contents of polysaccharides are also higher regarding Callisthene and Qualea (reaching $3.4 \%$ in sample 08, Q. grandiflora) than in Salvertia and Vochysia, with values mostly below 1\% (Table I).

The distribution of monomers of reserve polysaccharides in seeds of Vochysiaceae determines affinities between, Callisthene and Qualea, on one hand, and Salvertia and Vochysia, on the other. Thus, the predominance of arabinose and manose characterizes Callisthene and Qualea, while arabinose and glucose predominate in seeds of Salvertia and Vochysia. The monomer composition of polysaccharides of Vochysiaceae seeds, with the predominance of arabinose in all species, high manose content in seeds of Callisthene and Qualea and of galactose in Salvertia and Vochysia, comes close to the monomer carbohydrate profile of instant coffee (Mayworm et al. 2000).

\section{Oil Contents, Fatty Acid Profiles And}

Potential Commercial Uses

High contents of oil predominate in Vochysiaceae seeds, reaching up to $32 \%$ in $V$. pyramidalis, sample 52 (Table I). Contents of many samples analyzed are higher than those of soybean (12-24\%), sunflower (22$36 \%)$, cotton (19\%), tung (16-18\%), canola (2-49\%) and corn (2-5\%) (Simpson and Ogorzaly 1995). Such high oil yields are probably associated with the mode of seed dispersion. In fact, most Vochysiaceae seeds are wind dispersed, so that seeds contain low amounts of reserve, which contributes to reduce the seed weight. Since lipids contain twice the amount of energy as the same mass of protein or carbohydrate, storing oils as seed reservers represents an advantage for Vochysiaceae.
Seeds of $C$. minor yielded $20 \%$ of oil; oleic acid $\left(\mathrm{C}_{18: 1}\right)$ predominates $(72 \%$, Table $\mathrm{I})$, resembling canola and olive oils (71\%), a condition considered ideal for human consumption. The average content of Qualea seeds analyzed is $22 \%$. In seeds of $Q$. cordata, the amount of oleic acid comes close to $80 \%$, similarly to C. minor. But in seeds of of $Q$. grandiflora, the predominant acid is lauric $\left(\mathrm{C}_{12: 0}\right)(72-97 \%)$, along with other short carbon chains acids, such as capric $\left(\mathrm{C}_{10: 0}, 1-9 \%\right)$ and myristic $\left(\mathrm{C}_{14: 0}, 1-8 \%\right)$ (Table I). Such fatty acids distribution turns the oil adequate for use in cosmetics and soap industry. The absence or low amounts of linoleic and polyunsaturated acids make it useful also for production of fried foods, which is a market dominated worldwide by palm oil (Berger and Ong 1985). Q. grandiflora seeds may contain up to $25 \%$ of oil (sample 11, Table I). Seeds of Q. multiflora and $Q$. parviflora contain $18-24 \%$ of oil, with a predominance of oleic (53-73\%) and palmitic $\left(\mathrm{C}_{16: 0}, 26-44 \%\right)$ acids (Table I).

Contents of seed oils of $S$. convallariodora vary considerably, ranging from 5\% (sample 29) to $26 \%$ (sample 25). Corresponding fatty acid distributions are unusual, with predominance of arachidic $\left(\mathrm{C}_{20: 0}, 12\right.$ $43 \%$ ), behenic (docosanoic, $\mathrm{C}_{22: 0}, 31 \%$ ) or eicosenoic acids $\left(\mathrm{C}_{20: 1}, 30 \%\right.$, sample 25$)$ (Table I), with proportions varying among samples of different populations. Sample 29 has exceptional amounts of oleic acid (Table I).

Seeds of Vochysia and Salvertia have similar distribution of fatty acids, with predominance of medium and long carbon chains (Mayworm and Salatino 2002). In seeds of $V$. lucida (samples 42-44) predominate eicosenoic and oleic acids and in seeds of $V$. pygmaea (sample 45), eicosenoic and docosenoic (possibly erucic, $\mathrm{C}_{22: 1}$ ) acids (Table I). Samples of $V$. thyrsoidea and V. tucanorum (46-48 and 49-51, respectively) presented the highest proportions of acids with long and monounsaturated carbon chains, standing out docosenoic, eicosenoic and, in $V$. thyrsoidea, behenic (i.e. docosanoic) acids (Table I). The contents of oil and the distribution of fatty acids similar to the oils of Crambe and Brassica (both with predominance of docosenoic acid) suggest a promising utilization of seeds of these species not for food, but for the production of lubricants (Piazza and 
Foglia 2001). Lineages of B. napus with high contents of erucic acid, such as the former lineages of rapeseed, are nowadays hardly available and has been substituted by varieties that produce canola oil (Piazza and Foglia 2001). Oils rich in erucic acid and in its hydrogenated derivative (behenic) are now also useful for production of surfactants, detergents, cosmetics and plastics.

Presently, species producing seeds with triglycerides bearing predominantly monounsaturated acids, such as V. lucida, V. pygmaea, V. thyrsoidea and V. tucanorum (Table I), are valuable as possible sources of oils for biodiesel synthesis. Triglycerides with predominance of either saturated or polyunsaturated acids are inconvenient for biodiesel production, the former because the product obtained will likely have high cloud points, and the latter because the biodiesel produced have no oxidative stability (too many unsaturations turn the product vulnerable to peroxidation). Oils adequate for biodiesel production must be rich in long chain and poor in unsaturated fatty acids (Pinto et al. 2005). Another advantage of Vochysia seed oils is that they would not compete either with edible seeds (e.g. soybean, corn and sunflower) or seeds valuable for any other technological applications (e.g. linseed and castor oil bean).

Seeds of $V$. pyramidalis have, in average, the highest content of oil (23-31\%) and a very rare characteristic of fatty acid distribution of seed oils: predominance or high amounts of stearic acid $\left(\mathrm{C}_{18: 0}\right)$. Relative amounts of stearic acid in samples of $V$. pyramidalis ranged from $27-43 \%$. The other most important fatty acid in $V$. pyramidalis seeds is oleic (37-57\%) (Table I). Similar distribution of fatty acids characterizes seeds of cocoa, used in the production of chocolate and cocoa butter, the latter being important for the production of lipsticks, suppositories and ovules, because high contents of stearic acid imply a high triglyceride melting points, a reason why cocoa butter is generally solid at room temperature. Differences in fatty acid composition are substantial among sample seeds of $V$. pyramidalis, the sample 52 bearing the highest content of stearic acid. The selection of genotypes being feasible, a possibility may be viewed of attainment of lineages with a composition close to cocoa butter. In addition to a potential use in the manufacture of cosmetics and pharmaceutical products, oils or fats with high amounts of stearic acid are interesting also in dietetics; differently from myristic and palmitic acids, stearic acid has been shown to have no effect on the levels of blood cholesterol (Crupkin and Zambelli 2008).

Other Vochysia species, such as V. elliptica, V. gardneri and $V$. rufa, have over $70 \%$ of their seed fatty acids based on oleic (48-88\%) and stearic (6$36 \%$ ) acids (Table I).

\section{Exploitation Strategies for Vochysiaceae Seeds}

Knowing the composition of the nutritional reserves is the first step toward the assignment of commercial uses for seeds. It is also important to take into account other factors, such as the presence of undesirable substances (e.g. alkaloids, toxic non-protein aminoacids, etc.), productivity, promptness of seed collection under conditions of extractivism and the possibilities of genetic breeding and introduction of the plant into cultivation regimen. The size and weight of Vochysiaceae seeds are not particularly favorable regarding their economic use. On the other hand, many Vochysiaceae species produce annually a great deal of fruits and seeds. Moreover, populations of some of these species comprise numerous individuals, which facilitate the collection of fruits. V. tucanorum has dense populations in field and forest vegetations covering a large area of Brazil (Bahia to Paraná and Mato Grosso). Similar examples are $Q$. grandiflora and $S$. convallariodora. Individuals of $V$. pyramidalis also produce large amounts of seeds and form dense populations. Noteworthy is the case of $V$. pygmaea, an endemic species of Serra do Cipó (Minas Gerais), growing in areas of "campos rupestres", which is a vegetation occurring at altitudes above $1,000 \mathrm{~m}$, on sandy or rocky soils, mainly in Minas Gerais, Bahia and Goiás states. The extremely reduced distribution of the species implies an endangerment. It is a rare example of Vochysiaceae with herbaceous habit. The small size of $V$. pygmaea individuals may be a characteristic that favors an adaptation to the cultivation regimen. A possible problem of slow growth rate by $V$. pygmaea individuals may be circumvented by selection and breeding. Exploitation of its products could be a step supporting the species preservation. 
Tropical tree species may be exploited as new food sources and afford benefits for local human populations engaged in their collection or cultivation. For example, Bactris gasipaes and Inga edulis from Amazon, Sclerocarya birraea from South Africa and $U a-$ paca kirkiana from tropical Africa (Zambia and Zimbabwe), have already gained importance in regions far outside their areas of natural distribution, a reason accounting for their inclusion in a list of priorities for introduction in large scale cultivation (Leakey 1991). An inventory has been raised of Amazon species used by local inhabitants, including Indians and "caboclos". Official funds have been provided to foster the sustainable use of non-woody forest resources, such as the implementation of extractive reserves, in view of the escalating threat of loss of natural vegetation caused by the overexploitation of certain resources, such as Brazil nuts (Bertholetia excelsa), açaí (Euterpe oleracea) and natural rubber (Hevea brasiliensis) (Dubois 1996). Large areas of the Amazonian Forest were assigned the role of extractive reserves. However, relatively few products have been exploited in these areas. The adequate conservation of extractive reserves depends upon the sustainable exploitation of a much higher diversity of species. Exploitation of Vochysiaceae seeds in preservation areas, such as extractive reserves, could be a promising possibility.

\section{ACKNOWLEDGMENTS}

Provision of funds from Conselho Nacional do Desenvolvimento Científico e Tecnológico, Brazil (CNPq) is acknowledged.

\section{RESUMO}

Teores de proteínas, carboidratos solúveis e óleos de sementes de 57 indivíduos de Vochysiaceae, compreendendo uma espécie de Callisthene, seis de Qualea, uma de Salvertia e oito de Vochysia foram determinados. As principais reservas de sementes de Vochysiaceae são proteínas ( $20 \%$ em média) e óleos $(21,6 \%)$. A média dos teores de carboidratos foi de 5,8\%. Callisthene apresentou o mais baixo teor de proteínas (16,9\%), enquanto $Q$. cordata foi a espécie com o mais elevado teor (30\% em média). Teores de carboidratos solúveis em etanol foram muito superiores aos solúveis em água. Os teores de óleo foram superiores a $20 \%$ na maioria das espécies $(30,4 \%$ em $V$. pygmaea e $V$. pyramidalis). Ácidos graxos predominantes foram láurico (Q. grandiflora), oleico (Qualea e Salvertia) ou ácidos com cadeias mais longas (Salvertia e um grupo de espécies de Vochysia). A distribuição de ácidos graxos de Vochysiaceae sugere para as sementes de algumas espécies o uso em alimentação (predominância de ácido oléico), para outras, uma alternativa à manteiga de cacau (teores elevados de ácido esteárico) ou produção de lubrificantes, tensoativos, detergentes, cosméticos e plásticos (predominância de ácidos com cadeias $\mathrm{C}_{20}$ ou $\mathrm{C}_{22}$ ) ou biodiesel (predominância de ácidos monoinsaturados). Discute-se a possibilidade de aproveitamento de produtos de Vochysiaceae em regime de cultivo e em reservas extrativas.

Palavras-chave: biodiesel, carboidratos, ácidos graxos, proteínas, óleos de semente, Vochysiaceae.

\section{REFERENCES}

Ahmad UM, Husain SK And OSMAn SM. 1981. Ricinoleic acid in Phyllanthus niruri seed oil. J Am Oil Chem Soc 58: 673-674.

Banerji R, Chowdhury AR, Misra G And Nigam SK. 1984. Butter from plants. Fette Seif Anstrichm 7: 279-284.

BARroso GM. 1984. Sistemática de angiospermas do Brasil, vol. 2. Viçosa: Universidade Federal de Viçosa, 377 p.

BERGER KG AND ONG SH. 1985. The industrial uses of palm and coconut oils. Oléagineux 40: 613-621.

Blanche CA, Hodges JD, Gomez AE And GonzALEZ E. 1991. Seed chemistry of the tropical tree Vochysia hondurensis. Forest Sci 37: 949-952.

BULLETIN OF THE INTERNATIONAL DAIRY FEDERATION. 2006. Comprehensive review of scientific literature pertaining to nitrogen protein conversion factors. Brussels: International Dairy Federation, Bulletin 405, 11 p.

Cavalcante PB. 1991. Frutas comestíveis da Amazônia. Belém: Museu Paraense Emílio Goeldi, 279 p.

CRUPKin M AND Zambelli A. 2008. Detrimental impact of trans fats on human health: stearic acid-rich fats as possible substitutes. Comp Rev Food Sci Food Safety 7: 271-279.

DE PAula JE. 1967. Estudos sobre Vochysiaceae - 1. Contribuição ao conhecimento da morfologia foliar de Erisma uncinatum Warming, E. calcaratum (Link) Warming e E. splendens Stafleu, da Amazônia. Bol Mus Para Emilio Goeldi, sér Bot 27: 3-12. 
DUBOIS JCL. 1996. Uses of wood and non-wood forest products by Amazonian dwellers. Unasylva 186: 8-15.

Dubois M, Gilles KA, Hamilton JK, ReBers PA AND SMITH F. 1956. Colorimetric method for determination of sugars and related substances. Anal Chem 28: 350 356.

Ducke A And Black GA. 1953. Phytogeographical notes on the Brazilian Amazon. An Acad Bras Cienc 25: 1-46.

EARle Fr, Glass CA, Geisinger GC, WolfF IA AND JONES Q. 1960. Search for new industrial oils IV. J Am Oil Chem Soc 37: 440-447.

HEYwOOD VH. 1993. Flowering plants of the world. London: Oxford University Press, 395 p.

Hess SC, Brum RL, Honda NK, CRUz AB, Moretto E, Cruz RB, Messana I, Ferrari F, Cechinel FiLHO V AND YUNES RA. 1995. Antibacterial activity and phytochemical analysis of Vochysia divergens (Vochysiaceae). J Ethnopharm 47: 97-100.

KitTur MH, Mahajanshetti CS, RaO KVSA AND LAKSHMINARAYANA G. 1982. Characteristics and composition of Abutilon pannosum and Hibiscus panduriformis seeds and oils. J Am Oil Chem Soc 59: 123-124.

KLEIMAN R AND PAYNE-WAHL K. 1984. Fatty acid composition of seed oils of the Meliaceae, including one genus rich in cis-vaccenic acid. J Am Oil Chem Soc 61: 18361838.

LEAKEY RRB. 1991. Potential for novel food products from agroforestry trees: a review. Food Chem 66: 1-14.

MAYWORM MAS, BuCKERIDGE MS AND SALATINo A. 2000. Composition of polysaccharides of seed cell walls and the taxonomy of Vochysiaceae. Phytochemistry 55: 581-587.

MAYWORM MAS AND SAlatino A. 1996. Fatty acid composition of 'cerrado' seed oils. J Sci Food Agric 72: 226-230.

MAYWORM MAS AND SAlatino A. 2002. Distribution of fatty acids and the taxonomy of Vochysiaceae. Biochem Syst Ecol 30: 961-972.

Mustafa J, Gupta A, Ahmad MS, Ahmad F And OSMAN SM. 1986. Cyclopropenoid fatty acids in Gnetum scandens and Sterculia pallens seed oils. J Am Oil Chem Soc 63: 1191-1192.
Piazza GJ AND Foglia TA. 2001. Rapeseed oil for oleochemical usage. Eur J Lipid Sci Technol 103: 450-454.

Pinto AC, GUARIEIRo LN, REZENDE MJC, RIBEIRO NM, Torres EA, Lopes WA, Pereir PAP ANd ANDrade JB. 2005. Biodiesel: an overview. J Braz Chem Soc 16: 1313-1330.

RAJYALAKSHMI P AND GEERVANI P. 1994. Nutritive value of the foods cultivated and consumed by the tribals of south India. Plant Foods Hum Nut 46: 53-56.

RAo PU. 1996. Nutritional composition and biological evaluation of mesta (Hibiscus sabdariffa) seeds. Plant Foods Hum Nutr 49: 27-34.

SiMPSON BB AND OgORZALY MC. 1995. Economic Botany. Plants in our world. New York: McGraw-Hill, 742 p.

Sotelo A, LuCAs B, GARZA L AND Giral F. 1990. Characteristics and fatty acid content of the fat of seeds of nine wild mexican plants. J Agric Food Chem 38: 1503-1505.

Souza CP, AzEvedo MLL, LOPES JLC, SARTi SS, SANTOS FILHo D, LOPES JNC, VICHNEWSKI W, NASI AMTT AND LEITÃo-FILHO HF. 1984. Quimioprofilaxia da esquistossomose: atividade moluscicida de produtos naturais: ensaios com caramujos adultos e desovas. An Acad Bras Cienc 56: 333-338.

Souza VC AND Lorenzi H. 2005. Botânica Sistemática. Nova Odessa: Instituto Plantarum de Estudos da Flora Ltda, $640 \mathrm{p}$.

Sundar RaO K AND LAKShMinarayana G. 1987. Characteristics and composition of six newer seeds and their oils. Fat Sci Technol 89: 324-326.

ZAMUR J, BERTUZZI HJ AND BRAZZACH ML. 1981. Goma de Vochysia bifalcata Warming como aglutinante em comprimidos. I - Princípio ativo solúvel (Dipirona). Rev Farm Bioquim Univ S Paulo 18: 39-46.

Zheleznov AV, SolonenKo LP AND Zheleznov NB. 1997. Seed protein of the wild and the cultivated Amaranthus species. Euphytica 97: 177-182. 